\title{
KREATIVITAS DAN INOVASI PELAKU KUBE
}

\author{
Yuce Sariningsih \\ Universitas Pasundan Bandung \\ yucesp@unpas.ac.id
}

\begin{abstract}
This research concerning the program evaluation from Social Ministry of Republic of Indonesia which have conducted a productive economic activity in form of small business group, that is called Kelompok Usaha Bersama (KUBE) for the poor woman. The aim and purpose of this research was to analyze their creativity and innovation. The research has been conducted in West Java-Indonesia, and determined 111 (one hundred and eleven) respondents as sample. The research employed explanatory survey method and the data sources was primary and secondary data. A Questionnaire, observation and structured interview have been choosen for the data gathering techniques, and has been analyzed by path analysis. The research finding showed that respondent in condition lack of creativity and innovation and the recommendation has been formulated by improving the entrepreuneurial spirit of KUBE's social advisor of KUBE.
\end{abstract}

Key Words: Creativity, Innovation, KUBE, entrepreuneurial spirit.

\begin{abstract}
Abstrak
Penelitian ini tentang evaluasi program KUBE yang dluncurkan oleh Kementerian Sosial Republik Indonesia untuk meningkatkan aktifias ekonomi produktif dalam bentuk usaha kelompok. Kegiatan ini dinamakan Kelompok Usaha Bersama (KUBE) yang ditujukan bagi masyarakat miskin. Tujuan penelitian adalah menganalisis kreatifitas dan inovasi KUBE yang dilaksanakan di Jawa Barat dengan mengambil sampel sebanyak 111 respnden. Riset menggunakan metode survey dan data diambil dari sumber primer dan sekunder. Teknik pengumpulan data yang digunakan adalah kuesioner dan observasi serta dianalisis dengan menggunakan analisis jalur. Hasil penelitian menunjukkan bahwa kreatifitas dan inovasi responden masih rendah, sehingga rekomendasi yang diajukan adalah meningkatkan jiwa kewirausahaan anggota KUBE dan pendamping sosialnya.
\end{abstract}

Kata kunci: Kreatifitas, Inovasi, KUBE, jiwa kewirausahaan.

\section{Pendahuluan}

Meningkatnya jumlah penduduk miskin mengakibatkan semakin rendahnya tingkat kesejahteraan penduduk, namun kewirausahaan yang intinya adalah kreativitas dan inovasi serta daya juang dan daya tahan dalam melaksanakan usaha kecil masih lemah, konsep kewirausahaan dengan mengelola usaha kecil belum dapat diaplikasikan sepenuhnya dalam mengatasi masalah kemiskinan di Indonesia. Beberapa penyebab kegagalan usaha kecil menurut Bustami et. al., (2007: 5) sebagai berikut:

- Tidak jelasnya tujuan hidup yang ditetapkan secara baik. 
- Kurangnya ambisi untuk mencapai sasaran di atas rata-rata.

- Pendidikan yang kurang memadai.

- Disiplin pribadi yang lemah.

- Pengaruh lingkungan yang kurang menguntungkan.

- Sikap suka menunda-nunda pekerjaan.

- Kurangnya ketekunan.

- Adanya sikap pribadi yang negatif.

- Keinginan yang terlalu berlebihan dibandingkan kemampuan.

- Kurangnya kekuatan dalam pengambilan keputusan.

- Kurangnya konsentrasi terhadap usaha.

- Kebiasaan hidup boros.

- Ketidakmampuan bekerjasama dengan mitra kerja.

Bentuk usaha ekonomi produktif menjadi salah satu dasar diluncurkannya program Kementerian Sosial pada tingkat nasional untuk mengatasi kemiskinan, yaitu dengan membentuk Kelompok Usaha Bersama (KUBE) pada tahun 2003, yang sejalan dengan konsep usaha mikro/kecil. Kelembagaan ini relevan untuk melaksanakan pembangunan sosial ekonomi melalui ekonomi kerakyatan pada strata masyarakat terbawah, yang harus mendapatkan dukungan dari berbagai pihak terutama pihak pemerintah pusat maupun daerah.

Semangat kewirausahaan menjadi salah satu komponen inti bagi individu dalam melaksanakan usaha untuk menggerakkan ekonomi kerakyatan, yang bertujuan untuk mengatasi kemiskinan di Indonesia sebagai dampak dari krisis ekonomi yang berkepanjangan. Kewirausahaan dapat menjadi indikator maju atau tidaknya suatu negara, namun kewirausahaan masih belum diminati oleh sebagian besar penduduk Indonesia. Rendahnya tingkat kewirausahaan di Indonesia dipublikasikan (dalam http://pikiranrakyat.web.id (2009), sebagai berikut: "Indonesia saat ini hanya memiliki $0,18 \%$ wirausaha (entrepreuneur) dari jumlah penduduk. Padahal Negara maju harus memiliki paling tidak $2 \%$ jumlah penduduk yang bergerak di sektor kewirausahaan".

Salah satu hambatan dalam mengatasi kemiskinan adalah rendahnya jumlah penduduk yang berwirausaha. Merujuk pada Badan Pusat Statistik Republik Indonesia (http://www.bps.go.id :2009): "Jumlah penduduk miskin pada Maret 2009 tercatat sebesar 31,53 juta jiwa atau sekitar 14,15 persen. Jumlah ini turun 2,43 juta jiwa dibandingkan Maret 2008 yang mencapai 34,96 juta jiwa atau sekitar 15,42 persen. Namun data menurunnya angka kemiskinan tetap menjadi perdebatan, karena pada kenyataannya masih banyak masyarakat Indonesia yang hidup di bawah garis kemiskinan.

Kelompok Usaha Bersama (KUBE) diharapkan dapat meningkatkan kondisi sosial ekonomi bagi masyarakat strata terbawah untuk memperbaiki dan meningkatkan taraf kehidupan, serta sekaligus mampu mengatasi kerawanan sosial yang diakibatkan oleh ketidakberdayaan dan ketidak mampuan ekonomi. Pengertian dan ruang lingkup KUBE menurut Kementerian Sosial Republik Indonesia adalah sebagai berikut:

1. Kelompok Usaha Bersama (KUBE) adalah kelompok warga atau keluarga binaan sosial yang dibentuk oleh warga atau keluarga binaan sosial yang telah dibina melalui proses kegiatan Program Kesejahteraan Sosial (PROKESOS) untuk melaksanakan kegiatan 


$\begin{array}{lcr}\begin{array}{l}\text { kesejahteraan } \\ \text { ekonomi }\end{array} & \text { sosial } & \text { dan usaha } \\ \text { dalam } & \text { semangat } \\ \text { kebersamaan } & \text { sebagai } & \text { sarana untuk } \\ \text { meningkatkan } & \text { taraf } & \text { kesejahteraan } \\ \text { sosialnya. } & & \end{array}$

2. KUBE merupakan metode pendekatan yang terintegrasi dan keseluruhan proses pelaksanaan Program Kesejahteraan Sosial (PROKESOS).

3. KUBE tidak dimaksudkan untuk menggantikan keseluruhan prosedur baku Program Kesejahteraan Sosial (PROKESOS), kecuali untuk Program Bantuan Kesejahteraan Sosial Fakir Miskin yang mencakup keseluruhan proses. Pembentukan KUBE dimulai dengan proses pembentukan kelompok sebagai hasil bimbingan sosial, pelatihan keterampilan berusaha, bantuan stimulan dan pendampingan.

Pelaksanaan KUBE juga masih menemui berbagai kendala, diantaranya dijelaskan berdasarkan hasil penelitian yang dilaksanakan Guntur (2009), ia mengemukakan bahwa: "Terdapat beberapa permasalahan berkaitan dengan pencapaian tujuan pengembangan Kelompok Usaha Bersama (KUBE), yang sangat bergantung kepada :

1) Pihak eksternal, yang terkait dengan sejauhmana peranan dan bantuan pihak pemerintah, sejauhmana peranan dan bantuan pihak dunia usaha, dan kepada sejauhmana peranan dan bantuan dari pihak kelompok/lembaga swadaya masyarakat, pihak perguruan tinggi, dan pihak-pihak lainnya yang mempunyai kepedulian terhadap kalangan bawah.

2) Pihak internal, yang terkait dengan kualitas kelembagaan KUBE, kemampuan modal ekonomi anggota, pendidikan dan pelatihan, jiwa kewirausahaan, strategi kemitraan, serta aspek-aspek lainnya".

Kondisi ekonomi global dengan persaingan yang sangat ketat dan berkecepatan tinggi saat ini menjadikan kreativitas tidak hanya menjadi sumber penting untuk pengembangan usaha, tetapi juga merupakan suatu kebutuhan agar usaha kecil tetap berlangsung hidup. Hambatan mental dan perasaan bersalah yang dibebankan kepada diri sendiri dapat mematikan kreativitas dan inovasi, yang merupakan inti dari kewirausahaan.

Makna inovasi pada penelitian tentang KUBE sebagai usaha kecil ini bukan inovasi yang luar biasa dari munculnya suatu produk, tetapi mengacu pada inovasi yang sederhana sesuai dengan pendapat Alma (2008: 55): "Inovasi pada usaha kecil yang dimaksud bukanlah suatu temuan yang luar biasa, tetapi suatu temuan yang menyebabkan berdayagunanya sumber ekonomi ke arah yang lebih produktif". Rendahnya tingkat kreativitas, inovasi dan keterampilan merupakan penyebab kegagalan usaha kecil dan menengah. Hal ini juga dialami oleh KUBE wanita, sehingga tetap dalam kondisi kehidupan yang miskin secara sosial dan ekonomi.

\section{Metode}

Metode penelitian yang digunakan adalah explanatory survey method yang bertujuan untuk memberikan gambaran tentang suatu masyarakat atau hubungan antara dua gejala atau lebih. Biasanya, penelitian deskriptif seperti ini menggunakan metode survey".

\section{II.1. Waktu dan Tempat}

Penelitian dilakukan selama 8 (delapan) bulan pada KUBE wanita di wilayah Kabupaten Bandung, Kabupaten 
Majalengka, Kabupaten Kuningan, Kota Cirebon. Kabupaten Garut, Kabupaten Ciamis, Kota Banjar di Propinsi Jawa Barat. Beberapa KUBE dipertimbangan sebagai pilot project program KUBE dengan penilaian cukup baik (Dinas Sosial Propinsi Jawa Barat, 2009), karena berdasarkan hasil monitoring dan evaluasi sampai saat ini kegiatan usaha di kalangan penerima bantuan masih berjalan dengan baik, meskipun belum mencapai kinerja yang optimal.

\section{II.2. Populasi dan Sampel Penelitian}

Unit analisis dalam penelitian ini adalah KUBE Wanita Rawan Sosial Ekonomi (WRSE) yang menerima bantuan usaha dalam bentuk uang dan barang-barang untuk pengembangan masing-masing kegiatan usahanya. Unit analisis juga merupakan populasi dalam penelitian ini, yang tinggal di Kabupaten Bandung, Kabupaten Majalengka, Kabupaten Kuningan, Kota Cirebon. Kabupaten Garut, Kabupaten Ciamis, Kota Banjar Propinsi Jawa Barat, yang telah menerima bantuan KUBE dalam bentuk uang atau barang-barang sebagai modal usaha untuk Tahun Anggaran 2008. Jumlah kelompok sebanyak 46 kelompok, yang terdiri dari 450 penerima bantuan.

Sampel diambil dengan menggunakan Proportionale Cluster Random Sampling. Pendekatan statistik dapat menentukan besarnya suatu sampel dengan memperkirakan besarnya simpangan baku (standard deviation) populasi, dan menetapkan kesalahan maksimum yang dapat diterima dalam menaksir rata-rata populasi.

Pengambilan sampel tahap pertama dilakukan dengan mengambil sampel kelompok sebesar $80 \%$ dari 46 kelompok dengan menggunakan cluster random sampling secara proporsional, sehingga diperoleh 36,8 atau 37 kelompok yang terdiri dari 360 penerima bantuan KUBE. Berdasarkan sampling klaster tersebut, maka diperoleh kelompok responden sebagai sampel yang dijelaskan pada tabel berikut ini:

Tabel 1. Sampel KUBE Wanita Rawan Sosial Ekonomi (WRSE) di Jawa Barat

\begin{tabular}{|c|c|c|c|}
\hline Lokasi & Alamat & Kelompok Jenis Usaha & $\begin{array}{l}\text { Jumlah } \\
\text { (Orang) }\end{array}$ \\
\hline Kab. Bandung & 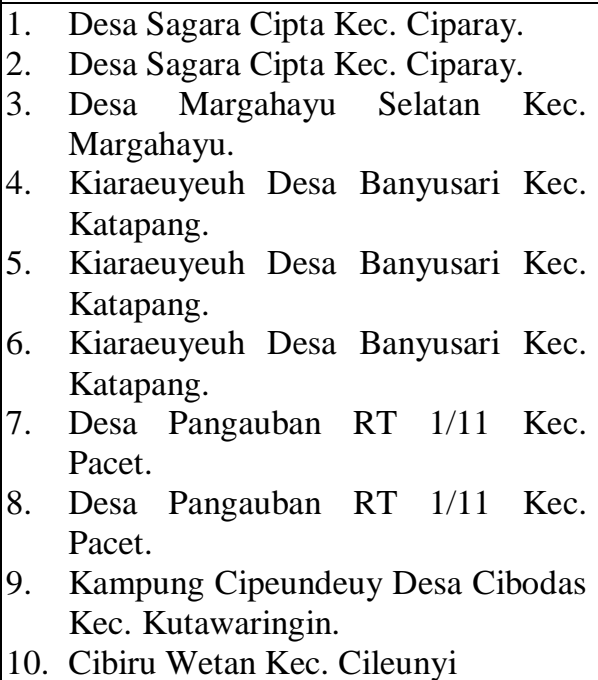 & $\begin{array}{l}\text { Pengrajin tas } \\
\text { Pengrajin tas } \\
\text { Olah pangan } \\
\text { Konveksi } \\
\text { Konveksi } \\
\text { Warungan } \\
\text { Sembako } \\
\text { Sembako } \\
\text { Tusuk Sate } \\
\text { Olah pangan }\end{array}$ & $\begin{array}{c}10 \\
10 \\
10 \\
10 \\
\\
5 \\
\\
10 \\
\\
10 \\
10 \\
\\
5 \\
10\end{array}$ \\
\hline $\begin{array}{l}\text { Kab. } \\
\text { Majalengka }\end{array}$ & $\begin{array}{l}\text { 1. Blok Sukamaju Desa Paniis Kec. } \\
\text { Maja. }\end{array}$ & Raginang & 10 \\
\hline
\end{tabular}




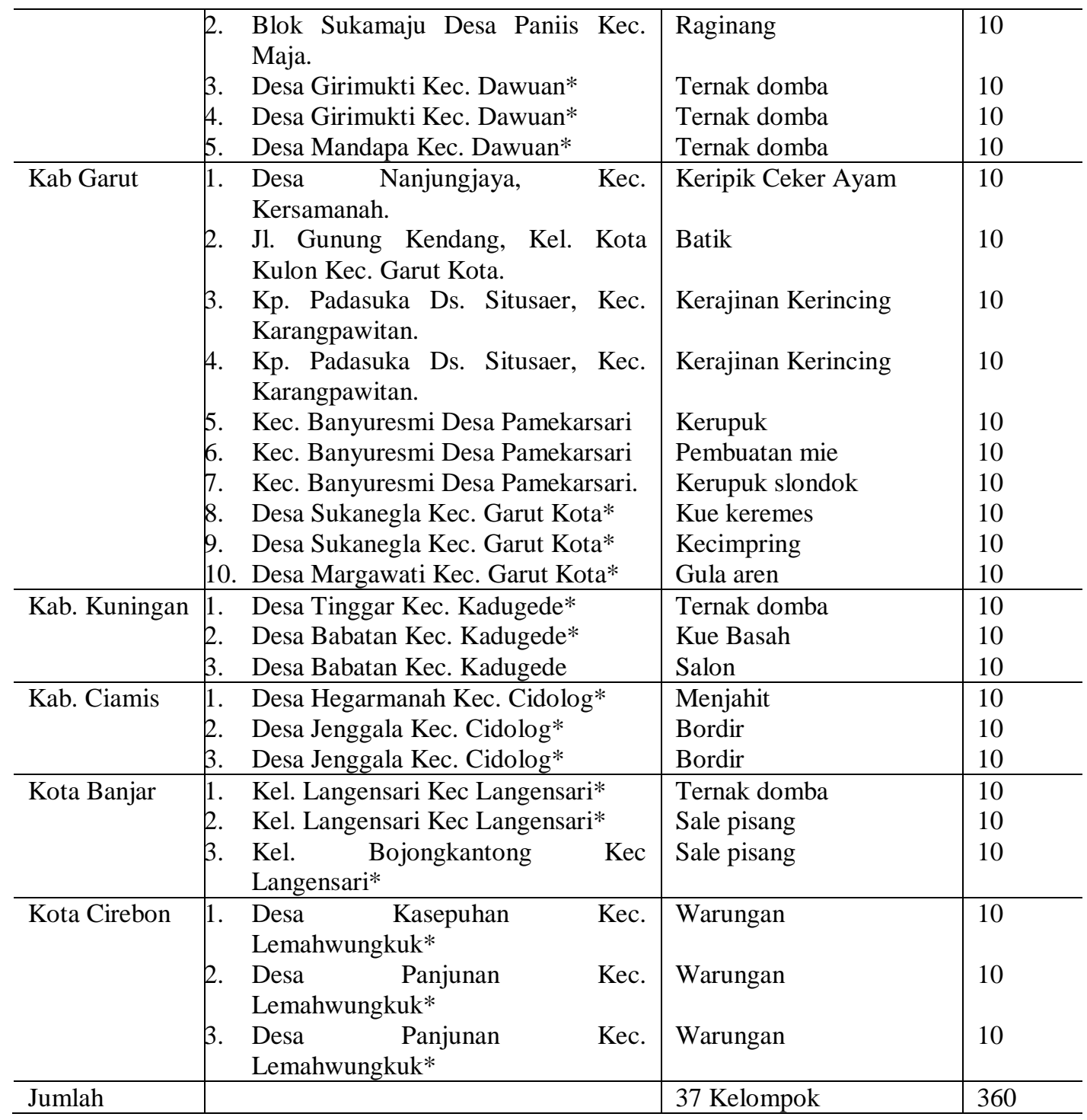

\section{Sumber: Dinas Sosial Propinsi Jawa Barat, tahun 2008}

Tahap kedua adalah dengan mengambil responden sebanyak 3 responden dari masing-masing kelompok sampel sesuai wilayahnya dengan kriteria sebagai berikut:

1. Sebagai ketua kelompok, atau sekretaris atau bendahara pada kelompok usaha bersama di masingmasing wilayah.

2. Terdaftar sebagai penerima bantuan usaha yang masih aktif menjalankan usahanya berdasarkan pemantauan pendamping sosial KUBE dari Dinas Sosial Propinsi Jawa Barat.
Berdasarkan kriteria tersebut, pada tahap kedua diperoleh sebanyak dari 37 kelompok sampel x 3 responden terpilih = 111 responden, yang mewakili dari masing-masing kelompok. Ukuran sampel tersebut telah memenuhi lebih dari jumlah sampel minimal sesuai dengan perhitungan sampel minimal sebelumnya.

Data yang dikumpulkan dalam penelitian ini adalah data primer dan data sekunder. Data primer dalam penelitian ini adalah data yang berasal dari hasil kuesioner yang merupakan 
jawaban atas serangkaian pernyataan yang direspon oleh responden, serta hasil pengamatan di area penelitian. Sedangkan data sekunder adalah data yang berkaitan dengan data dokumentasi tentang penyelenggaraan kegiatan usaha ekonomi produktif Kelompok Usaha Bersama (KUBE) wanita.

\section{II.3. Teknik Pengumpulan dan Pengolahan Data}

Untuk mendapatkan data primer dan sekunder digunakan teknik pengumpulan data dengan menggunakan kuesioner, observasi dan wawancara berstruktur, yaitu cara memperoleh data dengan mengadakan komunikasi langsung secara lisan atau tatap muka dengan responden yang diteliti, dan sumber data lainnya yang relevan. Teknk pengolahan data menggunakan kecenderungan sentral data.

\section{II.4.1. Pengujian Instrumen Penelitian}

Sebelum data diproses terlebih dahulu dilakukan uji validitas untuk menguji alat ukur atau kuesioner. Untuk mengukur validitas kuesioner dilakukan dengan metode korelasi product moment dari Pearson, yaitu hasil dari seluruh respon terhadap kuesioner yang berupa skor dikorelasikan. Valid tidaknya alat ukur tersebut dapat diuji dengan mengkorelasikan antara skor total yang diperoleh dari penjumlahan semua skor pertanyaan. Apabila korelasi antara skor total dengan skor masing-masing pertanyaan signifikan, maka dapat dikatakan bahwa alat pengukur tersebut dinyatakan valid. Sehubungan dengan hal tersebut,

Alat ukur yang digunakan dalam penelitian ini adalah kuesioner tertutup.
Teknik pengujian reliabilitas yang digunakan dalam penelitian ini yaitu uji reliabilitas dengan menggunakan teknik Cronbach Alpha. Dalam penelitian ini digunakan acuan $\alpha \geq 0,05$, sebagai kriteria alat ukur yang digunakan adalah baik (andal). Perhitungan keandalan alat ukur digunakan dengan memakai alat bantu pengolahan data statistik, yaitu program SPSS versi 13.

\section{II.4.2. Transformasi Data}

Kuesioner penelitian dirancang dengan menggunakan skala Likert mulai dari alternatif jawaban Sangat Setuju (SS), Setuju (S), Kurang Setuju (KS), Tidak Setuju (TS) dan Sangat Tidak Setuju (STS). Untuk keperluan analisis kuantitatif, data yang merupakan persepsi responden tentang variabelvariabel dalam penelitian ini akan diubah menjadi data kuantitatif.

\section{Hasil dan Pembahasan}

Tingkat dan besarnya perubahan yang mempengaruhi organisasi meningkat secara drastis, sehingga mengarah pada pentingnya manajemen stratejik dalam pengelolaan KUBE sebagai salah satu intervensi pekerjaan sosial, yang didasarkan pada kepercayaan bahwa organisasi seharusnya secara terus menerus memantau kejadian di lingkungan internal dan eksternal serta tren, dengan demikian perubahan yang cepat dapat dibuat ketika diperlukan. David (2006: 5) mengemukakan manajemen stratejik sebagai berikut: "Manajemen stratejik sebagai suatu seni dan ilmu untuk memformulasi, mengimplementasi, mengevaluasi keputusan lintas fungsi yang memungkinkan organisasi dapat mencapai tujuannya". Batasan tersebut menyiratkan bahwa manajemen stratejik berfokus pada mengintegrasikan 
manajemen,

pemasaran, keuangan/akuntansi, produksi/operasi, penelitian dan pengembangan, dan sistem operasi komputer untuk mencapai keberhasilan KUBE.

Hunger et. al., (2003: 2) menjelaskan pentingnya kemampuan manajer dalam hal ini ketua KUBE menjawab tiga pertanyaan strategis sebagai berikut: "Manajer dituntut untuk menambah pengetahuan dan praktik melalui pelatihan dan pengalaman dalam hal fungsional dan operasional, seperti akuntansi pemasaran, produksi atau keuangan, dan memperoleh gambaran menyeluruh, sehingga dapat menjawab tiga pertanyaan kunci strategis:

1. Di mana organisasi sekarang?

2. Jika tidak ada perubahan yang dibuat, dimana perusahaan akan berada dalam satu tahun ini, dua tahun, lima tahun, sepuluh tahun? Apakah dapat diterima?

3. Jika jawabannya tidak dapat diterima, tindakan khusus apa yang sebaiknya dilakukan oleh manajemen? Risiko dan hasil apa yang dilibatkan?".

Aplikasi manajemen stratejik sangat penting untuk keberlangsungan KUBE dan agar dapat beradaptasi terhadap perubahan, atau menjadi lebih buruk karena gagal menciptakan perubahan. Lingkungan di masa akan datang diprediksi lebih kompleks dan bergolak. Keputusan stratejik berhubungan dengan masa yang akan datang dalam jangka panjang untuk KUBE secara keseluruhan sesuai dengan karakteristik di atas, yang membuat risiko manajemen stratejik menjadi sangat tinggi.

Manajemen stratejik perlu diaplikasikan pada organisasi formal dalam skala mikro sekalipun seperti
KUBE, terutama untuk menghadapi ketidaktentuan kondisi perekonomian, serta pelaku KUBE tetap berusaha kreatif dan inovatif serta secara terus menerus meningkatkan kualitas keterampilannya, karena dihadapkan pada prospek usaha yang berorientasi ke masa yang akan datang. Konsep inovasi dalam manajemen stratejik pada KUBE bermakna kemampuan untuk mengelola sumber daya yang dimiliki secara efektif dan efisien perlu diwujudkan.

Pengelolaan KUBE harus mengacu pada manajemen karena bukan semata-mata kegiatan phylantrophy. Merujuk pada Pedoman Pelaksanaan dan Petunjuk Teknis, Dinas Sosial Pemerintah Propinsi Jawa Barat (2008): "Manajemen KUBE terdiri dari item indikator sebagai berikut:

1. Buku Keanggotaan; Buku tentang anggota yang dibuat untuk mengetahui jumlah anggota yang keluar dan masuk.

2. Buku Kegiatan Keanggotaan; Setiap kegiatan anggota seperti rapat, arisan atau kegiatan KUBE lainnya dicatat, sehingga dapat diketahui bersama laju aktivitasnya.

3. Buku Tabungan; Modal yang dikumpulkan, termasuk di dalamnya bantuan serta iuran kesetiakawanan sosial perlu dicatat dengan tertib.

4. Buku Keuangan; Buku ini untuk mencatat aset modal dan pengeluaran.

5. Buku Tamu; Buku ini mencatat pengunjung dari luar anggota kelompok yang ingin mengetahui perkembangan KUBE, seperti pendamping KUBE, tokoh masyarakat, petugas sosial dari Dinas Kota, Propinsi maupun Pusat, ataupun pihak-pihak lain yang mempunyai rasa kepedulian dengan keberadaan KUBE. 
6. Laporan Kegiatan; Karena banyak KUBE yang usahanya berbeda, maka perlu ada buku laporan secara berkala dari masing-masing KUBE".

Sebagaimana yang telah dijelaskan sebelumnya bahwa pada kebanyakan perusahaan kecil, manajemen yang buruk menjadi masalah utama dari kegagalan usaha, demikian juga hal ini dapat menjadi penyebab utama gagalnya KUBE dalam mencapai tujuan. Hal yang mematikan usaha kecil biasanya tidak banyak berhubungan dengan kekurangan uang, bakat atau informasi, akan tetapi lebih berhubungan dengan sesuatu yang lebih mendasar, yaitu kurangnya pemahaman dan pelaksanaan manajemen yang sesungguhnya harus diaplikasikan.

Struktur kelembagaan KUBE tergantung pada jenis usaha yang dijalankan, sehingga tidak ada struktur yang baku, namun struktur organisasi sederhana yang dapat dijadikan bahan acuan mengacu pada pada Pedoman Pelaksanaan dan Petunjuk Teknis, Dinas Sosial Pemerintah Propinsi Jawa Barat (2008) terdiri dari:
a. Ketua
b. Sekretaris
c. Bendahara
d. Anggota

Kreativitas dan inovasi merupakan inti dari kewirausahaan, dan kreativitas memiliki kaitan yang erat dengan inovasi. Zimmerer et. al., (2005: 41) menyatakan eratnya hubungan antara kreativitas, inovasi dan keterampilan dalam pengembangan usaha sebagai berikut: "Berpikir kreatif dan inovatif telah menjadi inti keterampilan bisnis, dan wirausahawan menjadi pemimpin dalam usaha mengembangkan dan menerapkan keterampilan tersebut. Pada kenyataannya, kreativitas dan inovasi sering menjadi jantung bagi kemampuan perusahaan kecil untuk dapat bersaing dengan pesaing mereka yang lebih besar"

Kreativitas dan inovasi juga merupakan kriteria kegiatan pendampingan sosial dalam pelaksanaan KUBE, sehingga anggota KUBE diharapkan memiliki kreativitas dan inovasi yang tinggi pula. Hal ini dinyatakan dalam Panduan Umum Pengembangan Usaha Ekonomi Produktif Fakir Miskin melalui KUBE dan LKM (2004; 115): "Setiap KUBE memiliki karakteristik yang khas dan spesifik, baik dari sumber daya, adat istiadat maupun kebiasannya. Oleh karena itu, pendamping sosial selain harus mampu menggali potensi untuk memanfaatkan sumber KUBE untuk dijadikan sumber pemberdayaan, juga harus mampu mengembangkan kreativitas dan daya inovasinya guna meningkatkan kemampuan anggota KUBE dalam mengenali dan mendayagunakan potensi yang dimilikinya. Kreativitas dan inovasi pada akhirnya menjadi tujuan dari anggota KUBE dalam menjalankan usahanya".

\section{III.1. Kreativitas}

Untuk membedakan antara kreativitas dan inovasi secara sederhana dikatakan bahwa creativity thinking new thing, innovation doing new thing, dan inovasi dikemukakan oleh Zimmerer et. al., (2005: 40) sebagai berikut: "Kemampuan untuk menerapkan solusi kreatif terhadap masalah dan peluang untuk meningkatkan atau memperkaya kehidupan orang-orang". Inovasi dan kreativitas merupakan fungsi utama dalam proses kewirausahaan. Wirausahawan dapat memadukan pikiran kreatif dan imajinatif dengan 
kemampuan proses yang logis dan sistematis. Wirausahawan yang potensial selalu mencari kesempatan yang unik untuk memenuhi kebutuhan dan keinginannya.

Kreativitas dan inovasi adalah dua konsep yang tidak terpisah, yang dikemukakan oleh Wirasasmita (2008: 5): "Kreativitas adalah gagasan baru, sedangkan inovasi adalah komersialisasi/aplikasi dari gagasan baru". Untuk menciptakan usaha yang lebih inovatif, KUBE harus mengembangkan budaya kewirausahaan sebagai budaya yang terbuka terhadap alih teknologi baru ke dalam produk dan aktivitas usaha. KUBE harus fleksibel, mampu menerima perubahan dan bersedia menerima kegagalan sebagai jalan menuju sukses. Inovasi merupakan hasil pencarian suatu kesempatan yang dilakukan dengan sepenuh hati.

Kreativitas tidak begitu saja terjadi dalam suatu organisasi, wirausahawan harus menciptakan lingkungan yang dapat menyuburkan kreativitas, bagi diri sendiri maupun lingkungannya. Upaya tersebut dijelaskan oleh Zimmerer et. al., (2005: 52): "Wirausahawan dapat merangsang kreativitas mereka sendiri dan mendukung kreativitas di antara pekerja dengan cara-cara berikut ini:

1. Menerima keragaman; mempekerjakan orang-orang dengan berbagai macam latar belakang, pengalaman budaya, hobi dan minat.

2. Memperkuat ide kreatif; memberikan ijin bagi karyawan untuk menjadi kreatif.

3. Mentolerir kegagalan; kreativitas membutuhkan pengambilan peluang, dan manajer harus menghilangkan perasaan takut karyawan akan kegagalan.
4. Mendorong rasa ingin tahu; mampu mendobrak asumsi-asumsi yang membatasi kreativitas.

5. Memandang masalah sebagai tantangan; setiap masalah manawarkan peluang untuk kreativitas.

6. Memberikan pelatihan kreativitas; hampir semua orang memiliki kapasitas untuk menjadi kreatif, tetapi mengembangkan kapasitas tersebut memerlukan pelatihan.

7. Memberikan dukungan; Wirausahawan harus memberikan alat dan sumber daya yang diperlukan oleh karyawannya agar bisa menjadi kreatif. Salah satu sumber daya yang bernilai adalah waktu.

8. Mengembangkan prosedur untuk menangkap ide-ide; tidak setiap organisasi siap untuk menangkap ide-ide kreatif, yang layak disayangkan adalah bahwa ide-ide bisa saja menguap.

9. Memberikan penghargaan atas kreativitas; Penghargaan financial dapat menjadi motivator efektif dalam perilaku kreatif, tetapi penghargaan non moneter-pujian, pengakuan, dan perayaan-dapat lebih menjadi insentif yang sangat kuat".

Secara sederhana, kreativitas mempengaruhi kemampuan permodalan yang tercermin pada kemampuan KUBE dalam pembukuan, hal ini menjadi komponen penting dalam pelaksanaan usaha meskipun dilaksanakan secara sederhana, yakni dalam bentuk buku-buku manual seperti buku catatan, agenda atau bahkan dalam kertas-kertas lainnya. Salah satu tujuan pembukuan ini adalah agar usaha kecil mendapatkan bantuan modal usaha, yang dinyatakan oleh Golrida (2008: 1): "Laporan keuangan usaha kecil sebagai 
wujud kreativitas diperlukan untuk mencapai tujuan yang sederhana, yakni mengevaluasi kinerja dan alat perencanaan usaha, serta mendapatkan dana dari institusi keuangan, khususnya perbankan untuk mengembangkan usaha".

Kreativitas yang muncul untuk pengembangan usaha kecil tidak akan berarti tanpa diwujudkan dalam suatu tindakan, yaitu dalam bentuk inovasi. Inovasi yang dikemukakan oleh Zimmerer et. al., (2005: 40) adalah: "Kemampuan untuk menerapkan solusi kreatif terhadap masalah dan peluang untuk meningkatkan atau memperkaya kehidupan orang-orang". Inovasi dan kreativitas merupakan fungsi utama dalam proses kewirausahaan. Wirausahawan dapat memadukan pikiran kreatif dan imajinatif dengan kemampuan proses yang logis dan sistematis.

Variabel kreativitas terdiri dari sub variabel menerima keragaman dan memperkuat ide kreatif, mentolerir kegagalan dan meningkatkan rasa ingin tahu, serta memandang masalah sebagai tantangan, dan keinginan mengikuti pelatihan kreativitas. Variabel ini diwakili oleh lima belas item pernyataan. Berdasarkan hasil pengumpulan data yang mengacu pada kuesioner, diperoleh skor rentang nilai data untuk variabel kreativitas yang diwakili oleh lima balas item pertanyaan untuk 111 responden, yaitu nilai skor pada $\Sigma \mathbf{f i} . \mathbf{X i}=5182$, dan skor ini cenderung pada jawaban kriteria sedang, sehingga dapat dikatakan bahwa responden cukup kreatif dalam mengelola KUBE, meskipun masih terdapat sejumlah responden yang memberikan jawaban kurang setuju. Hasil perhitungan pada tabel yang menghasilkan total nilai skor $\Sigma \mathbf{f i}$. Xi = 5182 digambarkan pada kontinum sebagai berikut:

\begin{tabular}{|c|c|c|c|c|}
\hline Sangat Rendah & Rendah & Sedang & Tinggi & Sangat Tinggi \\
\hline 1665 & 3330 & 4995 & 6660 & 8325 \\
\hline
\end{tabular}

Gambar rentang nilai di atas menunjukkan bahwa posisi kecenderungan jawaban responden untuk variabel kreativitas berada pada kecenderungan jawaban cukup kreatif. Rata-rata hitung pada skor variabel kreativitas adalah sebesar 3,315, artinya bahwa rata-rata jawaban responden tentang kreativitas berada di antara pilihan jawaban yang menyatakan cenderung setuju untuk keseluruhan item pernyataan. Hal ini berarti sebagian besar responden cukup memiliki ide kreatif dalam mengelola KUBE.
Data menggambarkan bahwa responden KUBE berusaha menunjukkan kreativitas. Namun secara empiris, pemahaman tentang kreativitas di kalangan responden masih terbatas, meskipun kreativitas menjadi salah satu tujuan kegiatan KUBE wanita. Ketentuan ini mengacu pada Pedoman Pelaksanaan dan Petunjuk Teknis, Kegiatan Bimbingan Usaha Ekonomis Produktif bagi Wanita Rawan Sosial Ekonomi (2008) bahwa: "Salah satu tujuan kegiatan adalah terwujudnya jiwa kemandirian dan kewirausahaan dalam diri Wanita Rawan Sosial Ekonomi 
(WRSE), guna menciptakan lapangan usaha yang lebih baik sebagai sumber penghasilan yang bermanfaat untuk kelangsungan hidup keluarga yang layak". Jika kewirausahaan menjadi tujuan, maka kreativitas menjadi komponen penting bagi pencapaian tujuan KUBE, sehingga rendahnya pemahaman responden tentang kreativitas menjadi masalah yang harus menjadi pertimbangan dalam pengembangan usaha ekonomi produktif.

Zimmerer et. al., (2005: 48) menyatakan bahwa: "Jumlah halangan potensial terhadap kreativitas sebenarnya tidak terbatas, yaitu tekanan waktu, manajemen yang tidak mendukung, rekan kerja yang pesimis, kebijakan yang terlalu kaku, dan hal-hal lain yang tak terhitung banyaknya. Akan tetapi, halangan yang paling sulit diatasi adalah halangan yang ditimbulkan oleh orang itu sendiri".

Untuk mengatasi masalah
tersebut, diantaranya teknik brainstorming, mind mapping dan rapid prototyping dapat membantu responden untuk meningkatkan kreativitas dalam mengelola usaha ekonomi produktif. Ketiga teknik tersebut dapat membuka mental locks anggota KUBE, namun dalam pelaksanaannya harus dibantu oleh tim pendamping sosial yang solid, namun pada kenyataannya responden belum sepenuhnya menjalin komunikasi yang baik di lingkungan KUBE dengan pendamping sosial.

Upaya peningkatan kreativitas responden dengan menggunakan teknik brainstorming telah dilakukan oleh pendamping sosial dengan merujuk pada Buku Pegangan Pendamping Sosial Cara Mudah membangun Kerjasama Kelompok Usaha Bersama/KUBE (2005: 134) yang menyatakan: "Latihan yang ditujukan bagi peserta KUBE bertujuan untuk membangun tim, pemecahbekuan, energi, kreativitas dan kegembiraan". Namun, diperlukan pendamping sosial yang telah terlatih untuk mencapai tujuan dimaksud.

\section{III.2. Inovasi}

Inovasi yang berhasil pada umumnya sederhana dan terfokus, dan ditujukan pada aplikasi yang didesain khas, jelas dan cermat. Inovasi lebih banyak melibatkan kerja fisik daripada pemikiran. Inovasi bagi KUBE lebih bersifat memanfaatkan perubahan daripada menciptakannya. Mencari inovasi dilakukan dengan memanfaatkan perubahan pada penemuan yang menyebabkan terjadinya perubahan. Inovasi berkaitan erat dengan kreativitas, hal ini dinyatakan juga oleh Machfoedz et. al., (2004: 19) bahwa: "Ide inovatif dapat bersumber pada kreativitas eksternal dan kreativitas internal". Upaya inovatif perlu dilakukan secara berkesinambungan meskipun suatu organisasi/perusahaan telah berhasil mencapai tujuannya. Matrik pasar produk baru, baik barang atau jasa, yang lebih baik merupakan alat yang tepat untuk melakukan inovasi. Wirasasmita (2008: 5) menyatakan: "Kreativitas adalah gagasan baru, sedangkan inovasi adalah komersialisasi/aplikasi dari gagasan baru".

Variabel inovasi merupakan variabel kedua dalam penelitian ini, yang terdiri dari sub variabel kemampuan menggunakan solusi kreatif terhadap masalah, dan kemampuan menggunakan solusi kreatif dalam memanfaatkan peluang. Variabel ini diwakili oleh tujuh belas item pernyataan. Inovasi pada penelitian ini 
adalah kemampuan responden dalam memanfaatkan sumber-sumber yang ada secara efektif dan efisien. Ukuran inovasi adalah dalam bentuk respon dari responden (pengelola KUBE) yang berkaitan dengan kemampuan menggunakan solusi kreatif dalam menghadapi masalah serta kemampuan menggunakan solusi dalam pengelolaan usaha.

Berdasarkan hasil pengumpulan data yang mengacu pada kuesioner, diperoleh skor rentang nilai data untuk variabel inovasi yang diwakili oleh tujuh belas item pertanyaan untuk 111 responden. Rentang nilai diperoleh dari perkalian antara jumlah responden dengan 17 item pernyataan, dan berada pada $\Sigma \mathbf{f i} . \mathbf{X i}=5680$. dan skor ini berada di antara jawaban pada kriteria cenderung sedang, sehingga dapat dikatakan bahwa responden cukup inovatif dalam memanfaatkan sumbersumber, yang digambarkan pada kontinum sebagai berikut:

\begin{tabular}{|c|c|c|c|c|}
\hline Sangat Rendah & Rendah & Sedang & Tinggi & Sangat Tinggi \\
\hline 1887 & 3774 & 5661 & 7548 & 9435 \\
\hline
\end{tabular}

Gambar rentang nilai di atas menunjukkan bahwa posisi kecenderungan jawaban responden untuk variabel inovasi berada pada jawaban cukup inovatif. Rata-rata hitung pada skor variabel inovasi adalah sebesar 3,201, artinya bahwa rata-rata jawaban responden tentang inovasi berada pada kategori cukup inovatif dalam mengelola usaha ekonomi produktifnya melalui KUBE.

Inovasi pada KUBE yang dikelola oleh responden yang dimaksud bukanlah suatu temuan yang luar biasa, tetapi suatu temuan yang menyebabkan berdayagunanya sumber ekonomi ke arah yang lebih produktif, sesuai dengan yang dikemukakan oleh Alma (2008: 55) bahwa: "Inovasi pada usaha kecil yang dimaksud bukanlah suatu temuan yang luar biasa, tetapi suatu temuan yang menyebabkan berdayagunanya sumber ekonomi ke arah yang lebih produktif'.

Fakta secara empiris dapat dimaknai belum optimalnya inovasi sebagai wujud kreativitas responden, Namun, sekitar setengah dari jumlah responden dapat mewujudkan inovasi dalam pengembangan usahanya. Jika kewirausahaan menjadi tujuan, maka seperti halnya kreativitas, maka inovasi menjadi komponen penting bagi pencapaian tujuan KUBE, karena inti dari jiwa kewirausahaan adalah kreativitas dan inovasi, sehingga keterbatasan pemahaman responden tentang inovasi dalam pelaksanaan KUBE dapat menjadi halangan internal dalam pengembangan usaha ekonomi produktifnya.

Berdasarkan Panduan Umum Pengembangan Usaha Ekonomi Produktif Fakir Miskin melalui Kelompok Usaha Bersama (KUBE) dan Lembaga Keuangan Mikro (LKM), Departemen Sosial RI, (2004: 64) bahwa salah satu strategi pengembangan KUBE adalah: "Penerapan inovasi-inovasi baru dalam pengembangan dan pengelolaan jenis usaha yang dipilih". Strategi ini 
mengindikasikan suatu capaian target inovasi yang harus dicapai oleh peserta KUBE, sehingga peningkatan kemampuan responden agar dapat mendayagunakan sumber ekonomi ke arah yang lebih produktif menjadi suatu kebutuhan untuk pencapaian tujuan kelompok.

Penetapan inovasi sebagai salah satu strategi pengembangan KUBE mengarah pada penguatan arti bahwa peserta KUBE adalah mereka yang diharapkan memiliki kemampuan menerapkan solusi kreatif. Merujuk pada Zimmerer et. al., (2005: 40) bahwa inovasi adalah: "Kemampuan untuk menerapkan solusi kreatif terhadap masalah dan peluang untuk meningkatkan atau memperkaya kehidupan orang-orang". Namun tingkat inovasi di kalangan responden masih harus ditingkatkan, yang ditunjukkan dengan belum optimalnya kemampuan dalam mengaplikasikan solusi kreatif terhadap masalah dan peluang yang ada, rendahnya motivasi dalam menjalankan usaha, kurang berorientasi dalam peningkatan modal usaha (tidak memiliki keberanian untuk menanggung resiko terkait dengan pinjaman modal usaha) dan inovasi dalam memanfaatkan peluang.

\section{III.3. Kesejahteraan}

Variabel kesejahteraan merupakan outcome dalam penelitian ini, yang terdiri dari sub variabel pemenuhan kebutuhan fisik dan ekonomi serta mental dan sosial. Variabel ini diwakili oleh delapan belas item pernyataan. Kesejahteraan $\left(\mathrm{Z}_{2}\right)$ pada penelitian ini adalah terpenuhinya kebutuhan fisik dan ekonomi, serta terpenuhinya kebutuhan mental dan sosial KUBE wanita. Kondisi ini merupakan tujuan akhir dari program Usaha Ekonomi Produktif melalui Kelompok Usaha Bersama.

Berdasarkan hasil pengumpulan data yang mengacu pada kuesioner, diperoleh skor rentang nilai data untuk variabel tingkat kesejahteraan yang diwakili oleh delapan belas item pertanyaan untuk 111 responden. Rentang nilai diperoleh dari perkalian antara jumlah responden dengan 18 item pernyataan, dan selanjutnya dikalikan dengan skor alternatif jawaban, sehingga diperoleh total skor kecenderungan jawaban untuk variabel tingkat kesejahteraan, yaitu sebesar $\Sigma$ fi. $\mathbf{X i}=5964$, dan skor ini berada di antara jawaban pada kriteria rendah menuju sedang, sehingga dapat dikatakan bahwa tingkat kesejahteraan responden pada kategori cukup baik. Perhitungan pada tabel yang menghasilkan total nilai skor $\Sigma \mathbf{f i} . \mathbf{X i}=5964$ digambarkan pada kontinum sebagai berikut:

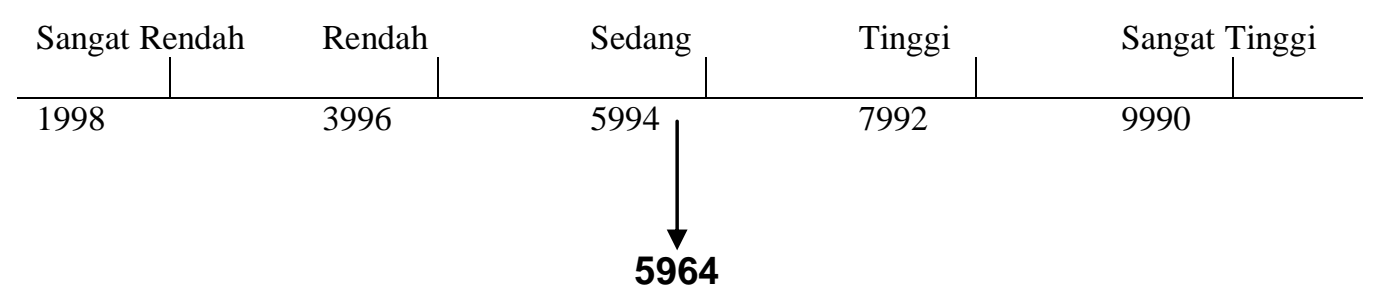

Gambar rentang nilai di atas menunjukkan bahwa posisi kecenderungan jawaban responden untuk variabel tingkat kesejahteraan berada pada rentang jawaban rendah menuju sedang. Rata-rata hitung pada 
skor variabel kesejahteraan adalah sebesar 2,943, artinya bahwa rata-rata jawaban responden tentang kesejahteraan berada pada kategori sedang. Hal ini berarti hampir setengah dari jumlah responden belum mendapatkan taraf kesejahteraan yang diharapkan dari kegiatan KUBE.

Kesejahteraan penerima bantuan juga tercantum dalam Pedoman Pelaksanaan dan Petunjuk Teknis, Kegiatan Bimbingan Usaha Ekonomis Produktif bagi Wanita Rawan Sosial Ekonomi (WRSE), Dinas Sosial Jawa Barat (2008: 3) bahwa: "Tujuan kegiatan adalah:

1. Meningkatnya perilaku kebersamaan, kesetiakawanan dan kepedulian social di kalangan masyarakat, khususnya Wanita Rawan Sosial Ekonomi (WRSE) dalam melalui proses usaha bersama dalam bentuk KUBE.

2. Meningkatnya keterampilan Wanita Rawan Sosial Ekonomi (WRSE) dalam usaha agar mau dan mampu melaksanakan peran dan fungsi sosialnya secara berdaya guna dalam kehidupan keluarga dan masyarakat.

3. Terwujudnya jiwa kemandirian dan kewirausahaan dalam diri WRSE guna menciptakan lapangan usaha yang lebih baik sebagai sumber penghasilan, yang bermanfaat untuk kelangsungan hidup keluarga yang layak.

4. Meningkatnya kesejahteraan sosial keluarga dari Wanita Rawan Sosial Ekonomi (WRSE) secara wajar dan layak.

KUBE merupakan kumpulan sekelompok orang yang menyelenggarakan usaha ekonomi produktif, yang tujuannya untuk mencapai kesejahteraan para anggotanya dalam organisasi tersebut.
Program ini dibiayai oleh Kementerian Sosial, yang merupakan salah satu bentuk usaha untuk mewujudkan kesejahteraan sosial berdasarkan perspektif dari intervensi profesi pekerjaan sosial dalam bentuk usaha ekonomi produktif. Tolok ukur kesejahteraan juga mengacu pada Thackeray., et al., (2004: 3) bahwa: Social welfare, in abroad sense, encompasses the well-being and interests of large numbers of people, including their physical, mental, emotional, spiritual, and economic needs". Hasil penelitian juga menunjukkan bahwa kohesivitas kelompok dalam organisasi KUBE sangat diperlukan. KUBE wanita dengan tingkat kesejahteraan yang cukup baik menunjukkan kohesivitas kelompok yang cukup kuat.

Pada dasarnya kesejahteraan dapat dicapai jika kinerjanya tinggi, yaitu ketika individu dan organisasi mampu menggunakan sumber-sumber yang langka tersebut secara optimal, dalam arti efektif dan efisien yang sepenuhnya digunakan untuk kemakmuran dan kesejahteraan masyarakat. Hal ini dikemukakan juga oleh George et. al., (2007: 7): "In any society or culture resources are valuable and scarce, so the more efficient and effective use that organizations can make of those resources, the greater the relative well being and prosperity of people in that society". Sumber-sumber yang ada sangat berharga dan langka, sehingga semakin efisien dan efektif organisasi menggunakan sumber-sumber tersebut, maka semakin besar kesejahteraan dan kemakmuran masyarakat.

Kesejahteraan menjadi salah satu tujuan penyelenggaraan KUBE, yang dikemukakan oleh Thackeray et. al., (1994: 3): "Social welfare, in a broad 
sense, encompasses the well being and interest of large numbers of people, including their physical, mental, emotional, spiritual, and economic needs. Economically it is a big business". Definisi tersebut menyiratkan bahwa pemenuhan kebutuhan dasar manusia tidak terlepas dari kegiatan-kegiatan usaha ekonomis produktif, karena melalui kegiatan tersebut diharapkan masyarakat yang kurang mampu mendapat penghasilan yang layak.

Indikator telah tercapainya taraf kesejahteraan anggota KUBE secara minimal dapat mengacu pada indikator keberhasilan KUBE yang dijelaskan pada Panduan Umum Pengembangan Usaha Ekonomi Produktif Fakir Miskin melalui KUBE dan Lembaga Keuangan Mikro/LKM (2004: 70) sebagai berikut: "Indikator keberhasilan anggota KUBE adalah sebagai berikut:

a. Bidang Kegiatan Kelembagaan

1. Kepengurusan dan pembagian tugas sudah ada dan sudah dijalankan sebagaimana mestinya.

2. Administrasi kelompok yang meliputi; buku daftar anggota kelompok, buku tamu, buku kegiatan/agenda kelompok, buku kas/keuangan, buku inventaris, buku simpan pinjam sudah ada dan sudah diterapkan dengan baik.

3. Kerjasama di antara anggota KUBE sudah berjalan dengan baik.

4. Proses pengambilan keputusan sudah didasarkan atas musyawarah anggota.

5. Pertemuan anggota sudah berlangsung secara rutin dan dilakukan pencatatan serta ditindaklanjuti.

b. Bidang Kegiatan Sosial
1. Motivasi berkelompok (potensi sosial) sudah baik yang ditunjukkan dengan minimal $2 / 3$ kehadiran anggota pada setiap pertemuan yang diadakan.

2. Kerjasama kelompok sudah baik yang dilihat dari koordinasi dan kekompakan kelompok.

3. Tanggung jawab sosial (antara anggota kelompok) sudah baik, yang ditunjukkan dengan kesediaan semua anggota untuk membantu anggota dan tetangganya yang mengalami kesulitan.

4. Kepedulian sosial (dengan luar anggota kelompk) sudah baik, yang ditunjukkan dengan adanya kepedulian semua anggota untuk membantu anggota dan tetangga yang mengalami kesulitan.

5. Usaha simpan pinjam KUBE sudah dapat dimanfaatkan keluarga untuk keperluan keluarga anggota KUBE.

6. Makanan sudah dapat memenuhi kriteria empat sehat lima sempurna.

7. Anak dapat mengikuti pendidikan yang sesuai dengan tingkat usianya dan peralatannya dapat dipenuhi.

8. Bila anggota keluarga jatuh sakit segera berobat ke mantri kesehatan atau bidan atau dokter atau ke Puskesmas.

9. Anggota keluarga taat dan sungguh-sungguh dalam menjalankan rukun keagamaannya.

10. Keluarga hidup dalam kaharmonisan.

11. Keluarga aktif dalam mengikuti kegiatan-kegiatan kemasyarakatan.

c. Bidang Kegiatan Ekonomi 
1. Sumber modal berasal dari kredit bersubsidi.

2. Meningkatnya pendapatan keluarga.

3. Kinerja usaha meningkat, mempunyai lebih dari dua jenis usaha.

4. Perkembangan usaha dimana KUBE dijadikan sebagai usaha pokok.

5. Kemampuan merencanakan usaha (pengurus dan anggota telah mampu menyusun RUB).

6. Tabungan dari waktu ke waktu terus bertambah bahkan berlipat ganda.

7. Peluang pasar cukup luas.

8. Kemampuan pemupukan modal dan sudah dapat memanfaatkan sumber dana yang ada untuk pengembangan usaha.

9. Simpan pinjam sudah berkembang dengan baik.

10. Kemitraan sudah terjalin dengan baik dengan berbagai kelompok masyarakat bisnis".

Longenecker et. al., (2001: 301) menyatakan bahwa: "Pendanaan awal dari bisnis berskala kecil sering berpola menurut tipikal perencanaan pendanaan pribadi. Seorang calon wirausahawan pertama kali akan menggunakan tabungan pribadi dan kemudian mencoba mendapatkan akses peningkatan modal usaha. Jika sumber ini tidak mencukupi, wirausaha akan mencari lebih banyak saluran resmi pendanaan, seperti bank dan investor dari pihak luar perusahaan". Dengan demikian, untuk mengelola modal kerja pelaku usaha harus inovatf, yang berarti kemampuan mengelola sumber-sumber ekonomi secara lebih efektif. Untuk meminimumkan resiko, Bustami et. al., (2007: 83) menyatakan: "Inovasi dalam arti penggunaan sumber daya ekonomi secara efektif diperlukan dalam pemilihan sumber dana untuk pembiayaan modal kerja, hutang dagang dan hutang jangka pendek lainnya”.

\section{Kesimpulan}

Berdasarkan hasil penelitian tentang analisis faktor-faktor yang mempengaruhi kemampuan permodalan dan pemasaran yang berimplikasi pada kinerja, serta dampaknya terhadap kesejahteraan Kelompok Usaha Bersama (KUBE) wanita di Jawa Barat, penulis menyimpulkan bahwa:

1. Kreativitas responden cukup baik yang ditunjukkan dengan kemampuannya untuk menerima keragaman dan memperkuat ide kreatif, mentolerir kegagalan dan meningkatkan rasa ingin tahu, serta memandang masalah sebagai tantangan dan keinginan mengikuti pelatihan untuk meningkatkan kreativitas dalam melaksanakan usaha ekonomi produktif melalui KUBE, namun kreativitas responden harus ditingkatkan agar dapat mengembangkan usahanya secara lebih baik. Beberapa kelompok responden telah mampu menunjukkan inovasi dengan memanfaatkan sumber-sumber yang ada untuk mengembangkan usahanya, namun belum sepenuhnya inovasi dapat diwujudkan sesuai dengan gagasan responden, hal ini ditunjukkan dengan masih rendahnya kemampuan dalam menerapkan solusi kreatif dalam pemecahan masalah dan memanfaatkan peluang. Responden telah menunjukkan keterampilan dalam bidang teknis dengan sangat baik dalam menghasilkan produk dan jasa, tetapi belum mampu menjalin mitra usaha, belum mampu menghadapi resiko 
usaha sepenuhnya dan berbagai masalah pengembangan usaha belum dapat diatasi dengan baik.

2. Beberapa kelompok responden sudah menunjukkan kemampuan permodalan yang baik dan mengharapkan terbentuknya koperasi untuk pengembangan modal usaha. Namun, sebagian besar dari sejumlah responden belum berani menanggung resiko untuk mengajukan pinjaman dana melalui bank, di samping itu kemampuan manajeral dan administrasi keuangan masih lemah, sehingga seringkali dinilai tidak bankable. Responden juga menunjukkan kemampuan pemasaran yang cukup baik dengan menjangkau pasar produk sampai ke luar Jawa, dan menjalin kemitraan pemasaran hasil usaha dengan outletoutlet di sekitar tempat produksi, meskipun demikian kemampuan akses terhadap pemasaran masih terbatas, serta pemahaman responden tentang bauran pemasaran yang terdiri dari $4 \mathrm{P}$, yaitu Product (produk), Price (harga), Promotion (promosi) dan Place (tempat) masih harus ditingkatkan.

3. Beberapa kelompok responden menunjukkan taraf kesejahteraan yang lebih baik. Responden dapat mewujudkan kreativitas dalam bentuk inovasi, yaitu kemampuannya dalam memanfaatkan sumbersumber yang tersedia secara efektif dan efisien, dengan demikian semangat kewirausahaan dan keterampilan responden terus menerus meningkat karena proses belajar dalam kelompok. Responden yang bekerja dalam kelompok pada umumnya menunjukkan daya tahan dan daya juang yang tinggi, menekuni pekerjaan, siap secara mental dan berani mengambil resiko sehingga dapat mencapai taraf kesejahteraan hidup yang lebih baik.

Berdasarkan uraian pembahasan dan kesimpulan yang telah dijelaskan di atas, peneliti merumuskan saran khusus dan saran umum sebagai berikut:

1. Menyelenggarakan pelatihan di lingkungan KUBE yang dikelola wanita untuk meningkatkan kreativitas dan inovasi.

2. Ksejahteraan wanita yang mengelola KUBE merupakan outcome dari kegiatan pengentasan kemiskinan ini, dengan demikian pihak pemerintah dan pengusaha selayaknya turut membantu perintisan kerja sama dengan berbagai pihak, khususnya dalam pembentukan koperasi, kemitraan dengan pihak perbankan, lembaga keuangan, asuransi, meningkatkan kemampuan peserta KUBE dalam mengakses dana Corporate Social Responsibility (CSR), serta memperluas jaringan pemasaran hasil usaha. Pihak pemerintah juga diharapkan menerbitkan kebijakan dalam bentuk fasilitas dan dukungan yang memadai dalam membangun berbagai kemitraan tersebut.

3. Penguatan peran tim pendamping sosial secara terus menerus dalam meningkatkan kreativitas, inovasi dan keterampilan, sehingga mampu mengakses informasi dan siap secara mental untuk mendapatkan penambahan modal usaha dari koperasi, perbankan atau sumber dana lainnya. Pendamping sosial hendaknya memiliki latar belakang pendidikan pekerjaan sosial dan memiliki pengetahuan yang memadai tentang manajemen Usaha Ekonomi Produktif, serta mampu menjadi mediator antara KUBE yang dikelola 
wanita dengan pihak pemerintah (government), akademisi (intellectuals) dan mitra bisnis (business).

\section{DAFTAR PUSTAKA}

Alma, Buchari., Prof., Dr., 2008. Kewirausahaan. Bandung: Alfabeta.

Badan Pusat Statistik Republik Indonesia. 2009. Jumlah Penduduk Miskin di Indonesia. Jakarta: http://www.bps.go.id

Bustami et.al. 2007. Mari Membangun Usaha Mandiri. Yogyakarta: Graha Ilmu.

Costa, Joana et.al. 2008. The Burden of Gender Inequalities for Society. Number 13, (January 2008), International Poverty Centre

Coulter, Mary K. 2001. Entrepreneurship in Action. New Jersey: Prentice-Hall, Inc.

Creswell, John W. 1994. Research Design, Qualitiative and Quantitative Approaches. California: Sage Publication.

Damsar, 2009. Pengantar Sosiologi Ekonomi. Jakarta: Kencana Prenada Media Group.

David, Fred R. 2006. Manajemen Strategis. Jakarta: Penerbit Salemba Empat.

Dessler, Gary. 2008. Manajemen Sumber Daya Manusia. Jakarta: PT. INDEX.

Dermawan Wibisono. 2006. Manajemen Kinerja. Konsep, Desain dan Teknik Meningkatkan Daya Saing Perusahaan. Jakarta: Erlangga.

Dinas Sosial Pemerintah Propinsi Jawa Barat. 2008. Pedoman Pelaksanaan dan Petunjuk Teknis, Kegiatan Bimbingan Usaha Ekonomi Produktif bagi Wanita
Rawan Sosial Ekonomi, Tahun Anggaran 2008. Bandung: Dinas Sosial Pemerintah Propinsi Jawa Barat.

Drucker. Peter F. 1985. Innovation and Entrepreneurship, Practice and Principles. New York: Harper \& Row Publisher.

Formula Bisnisnet. 2009. Kemandirian Pengelolaan KUBE. Jakarta: www.Formulabisnisnet.com,

Golrida. 2008. Akuntansi Usaha Kecil untuk Berkembang. Bandung: PT. Raja Grafindo Persada.

Gould, Gary M. \& Smith, Michael L. 1988. Social Work in the Workplace. New York: Springer Publishing Company.

Hadi, Didik Kurniawan. (Chief Economist Assistant PT. Recapital Advisors). 2008. Krisis Ekonomi. Jakarta: http://didikurniawan.web.id.

Halim, Neddy Rafinaldi. 2009. Kewirausahaan. Jakarta: Deputi Bidang SDM Kementerian Koperasi dan UKM, http://m.antaranews.com. Maret 2009].

Hendra Halwani. 2002. Ekonomi Internasional dan Globalisasi Ekonomi. Jakarta: Ghalia Indonesia.

Hunger, J., David et.al. 2003. Manajemen Strategis. Yogyakarta: Penerbit ANDI.

Indonesia Policy Briefs, 2005. Gagasan untuk Masa Depan. Jakarta: http://www.worldbank.or.id . [January 2005].

Jones, Gareth R. et.al. 2007. Essential of Contemporary Management. New York: The McGraw-Hill Companies. 
Karhi Nisjar. Dr. et.al. 1997. Manajemen Strategik. Bandung: CV. Mandar Maju.

Kementerian Sosial Republik Indonesia. 2005. Cara Mudah Membangun Kerjasama Kelompok Usaha Bersama (KUBE), Buku Pegangan Pendamping Sosial. Jakarta: Kementerian Sosial Republik Indonesia.

Lawrence, Katherine A. 2002. Creativity at Work. San Francisco: A Wiley Company.

Longenecker et.al. 2001. Kewirausahaan Manajemen Usaha Kecil. Jakarta: Penerbit Salemba Empat.

Mangkuprawira., Sjafri Dr., Ir. 2003. Manajemen Sumber Daya Manusia Strategik. Jakarta: Ghalia Indonesia.

Machfoedz, Prof. Dr., MBA. et.al. 2002. Kewirausahaan, Suatu Pendekatan Kontemporer. Yogyakarta: UPP AMP YKPN.

Meredith, Geoffrey G. 2005. Kewirausahaan, Teori dan Praktek. Jakarta: Penerbit PPM.

Moelyono, Mauled., Dr., SE., MA. Menggerakkan Ekonomi Kreatif. 2010. Jakarta: PT. RajaFrafindo Persada

Moser, Caroline O.N. 1993. Gender Planning and Development. Theory, Practice and Training. Canada: Routledge.

Muctar Sarman et.al. 2000. Masalah Penanggulangan Kemiskinan. Jakarta: Puspa Swara untuk P3RYAE.

Mujiyadi, MSW. 2008. Implementasi Program Pemberdayaan Fakir Miskin melalui Kelompok Usaha Bersama (KUBE). Jakarta: Studi Evaluasi di Delapan Daerah Indonesia
Mutalima, Irene. 2008. Microfinance for Gender Equality: A Dilemma? Christian Enterprise Trust of Zambia. Number 13, (January 2008), International Poverty Centre

Nindita Radyati, Maria. 2008. CSR untuk Pemberdayaan Ekonomi Lokal. Jakarta: Yayasan Indonesia Business Links.

Robbins, Stephen P. et.al. (Alih bahasa Harry Slamet). 2007. Manajemen. Jakarta: PT. Indeks.

Skidmore, Rex A et.al.. 1994. Introduction to Social Work. New Jersey: Prentice-Hall International Inc.

Soehartono., Irawan. Dr. 2000. Metode Penelitian Sosial. Jakarta: PT. Remaja Rosdakarya.

Thompson, Leigh et.al. 2006. Creativity and Innovation in Organizational Teams. New Jersey: Lawrence Erlbaum Associates Inc.,

Unnissula. 2008. Kelompok Usaha Bersama (KUBE). Jakarta: http://www.unissula.ac.id/

Wirasasmita, Yuyun. 2008. Kewirausahaan. Bandung: Universitas Pasundan.

Zimmerer, Thomas W. et.al.. 2005. Kewirausahaan dan Manajemen Bisnis Kecil. Jakarta: PT. Index.

\section{Biodata Penulis}

DR, Yuce Sariningsih, menempuh program Strata 1 di Sekolah Tinggi Kesejahteraan Sosial (1991), Progam Magister Jurusan Sosiologi konsentrasi Ilmu Kesejahteraan Sosial di Universitas Indonesia (2000), serta Program Doktoral Ilmu Manajemen di Universitas Pasundan (2011). Saat ini sebagai dosen tetap pada FISIP Universitas Pasundan jurusan Ilmu Kesejahteraan Sosial, Sekretaris 
Lembaga Penelitian Universitas

Pasundan, Ketua UPT Jurnal dan

Publikasi Universitas Pasundan serta

Reviewer Penelitian Bersertifikat

Kemenristekdikti dan Quantum pada

bidang Ilmu Manajemen. 